\title{
Forum
}

\section{A textile workshop to approach Classical civilisation}

\author{
Elena Miramontes Seijas \\ Avda. Rosalía de Castro 6, 3 A 15160 Sada (A Coruña), Spain
}

Key words: workshop, fashion, textile, society, appearance

\section{Introduction}

Every day teachers try to improve their students' awareness of how life was in Classical times. We talk about mythology, politics, the building of cities and many other aspects that made the ancient world, but what do we actually know and teach about clothing in ancient times? Our society seems to pay a lot of attention to the physical aspect of the ancient world. We know that clothing and adornment are important ways in which people were defined as a part of a social group, yet our students seem to believe that our ancestors just had a poor selection of national garments to make their identity clear.

Physical appearance in ancient times was a marker of ethnicity, social status, job, sex and age. Therefore, showing the difference in clothing in Classical Greece and Rome to our students can be an effective way to enable them to identify the role that characters described in written texts played and what behaviour was expected from everyone. Furthermore, this could become an easy visual way for them to realise the importance priests and military personnel had in ancient societies, and perhaps how surprising the differences between Western and Eastern societies seemed to have been.

Many different activities can be carried out in class, including, of course, the careful selection of texts which may illustrate the topic. Here, however, I suggest a workshop, which compares the clothing in Classical Athens with that of Classical Rome. This workshop could also be easily adapted to show, for instance, the evolution of fashion up to the end of the Roman Empire or to concentrate on another particular aspect of interest.

\section{Designing the workshop}

First, we should decide where we are going to hold the workshop, what its focus and audience will be. I would divide the room available into four sections:

1.-Textile technologies

2.-Greece

3.-Rome

4.-Activities and conclusions

Author of correspondence: Elena Miramontes Seijas. E-mail: eleseimi@gmail.com

Cite this article: Seijas E M (2021). A textile workshop to approach Classical civilisation. The Journal of Classics Teaching 22, 55-59. https://doi.org/10.1017/ S2058631021000088
If possible, the Greece and Rome sections should face each other and be divided into similar blocks, for a better visual effect and so that students can compare them more easily.

Even though teachers can explain the theory and use volunteers to maintain discipline, this kind of activity is usually more effective when students from higher grades take the lead. We could ask several students to learn and explain the basic theory and give instructions to their schoolmates. Then, students can be divided into several groups, according to how many there are. Each group passes through all sections, guided by one of the student-helpers who explains the theory and describes the activities. This way, teachers have more of a supervisory role, keeping control of discipline and helping the performance of activities to go right. At the same time, students from the lower grades keep more attention when listening to their older schoolmates and those from higher grades feel valued and appreciated, usually trying to make an extra effort to learn and understand what they have to explain.

\section{1.-Textile technologies}

Most of our students probably do not know how fabrics are made, what materials are typically used, or how clothes are dyed. Therefore, the first section in the workshop should be dedicated to clothing construction. Access to a loom or to fabrics of all kinds could enrich this section, giving students the opportunity to see the materials and to compare them with what they are wearing, so that they can try to guess the materials with which the fabric is made. However, pictures can also be displayed, to show them how to understand the process of making the cloth and the evolution of technology: it is interesting for the students to understand that the machines by which fabric was made may have changed, but the steps that are followed are basically the same as they were 2000 years ago.

As well as posters, I suggest that unless there is access to an upright loom, some small tablet looms can be provided. They are easily found in toy stores, similar to the ones that were used to create borders and other decorations. To this we can add small samples of wool, linen, leather, silk and cotton fibres and cloth. Since clothes were not plain, we can also show some pieces of dyed cloth, decorated with patterns, embroidered and woven in different colours (e.g. a piece of tapestry). The objective of this section is for students to understand the wide variety of decorations and materials that 
were used then and now by showing them the materials, tools and samples that were used.

As a note, we should remind students that the first materials used were leather and wool. The first required a barking process; the second had to be beaten, carded and spun before being woven. Linen was also used in ancient times, whereas cotton and silk appeared later, mostly imported from Asia, although some domestic silk production was present at the island of Cos. Once the thread was done, it could be coloured using dyes made from plants, together with different types of mordants, such as alum, which allowed the paint to be absorbed by the fabric and not to fade easily. Even though the most expensive colour was the purple obtained from the murex seashell, different methods of creating less expensive shades of purple arose during the Roman Empire and even gold garments became more common among the most powerful classes to show their status.

Weaving was a complex process in which women were expected to be skilled. However, men were also involved in textile manufacture when it had industrial and commercial purposes. It is interesting to observe that looms evolved over time. The ones that seem more familiar to us are typically horizontal, so that the weaver can sit down. In ancient Greek and Rome, however, they were placed vertically, probably standing against a wall and weavers tied the threads of the warp to lead weights which held them tight. Weavers worked standing, yet the loom was slightly different in Roman times: a spatha appeared, separating the warp threads alternatively in two and making it easier to know the direction that the weft thread had to follow across the warp.

As mentioned above, women were expected to be skilled at weaving. Not only did they know how to create a nice plain piece of cloth, but they could also intertwine threads of different colours to create pictures, use a variety of techniques to give it a different appearance, or even use oil and the finest threads to make clothing almost transparent. Nets could also be woven in smaller hand looms to decorate a lady's hair. Buttons and especially pins and brooches were used as ornaments and fastening devices. Purple stripes were usually woven in Roman clothes and sometimes colourful borders were attached to make garments look beautifully finished. The contact with the East would also add embroideries, beads and gold threads to enrich clothing. A garment could also be bleached to gain whiteness and fullones were experts in cleaning and treating clothes, even ironing or folding them in pleats with big presses.

In general, a wide variety of adornment, colour and material choices was available to ancient people, which made fashion rich and diverse.

\section{2.-Greece}

Clothing in Greece was relatively simple. Pictures were usually woven on clothes in archaic times; however democracy in Athens implied moderation and simplicity, as noblemen tried to fit in among the common people (Pavlou, 2009). Hellenism and the arrival of Rome implied a change in fashion, due not only to the opening to Eastern and later Western influences, but also to the rise of absolutist monarchies, which brought back the interest in showing social status (Llewellyn-Jones, 2003).

Focusing on the classical period and on those garments, which defined the Greek people, we must talk about the chiton and himation. Also, Greek men exercised fully naked and they uncovered their body more easily and comfortably than Romans (Heskel, 2001). They usually wore a tunic and sometimes a pallium, a rectangular piece of clothing to wrap around the body.

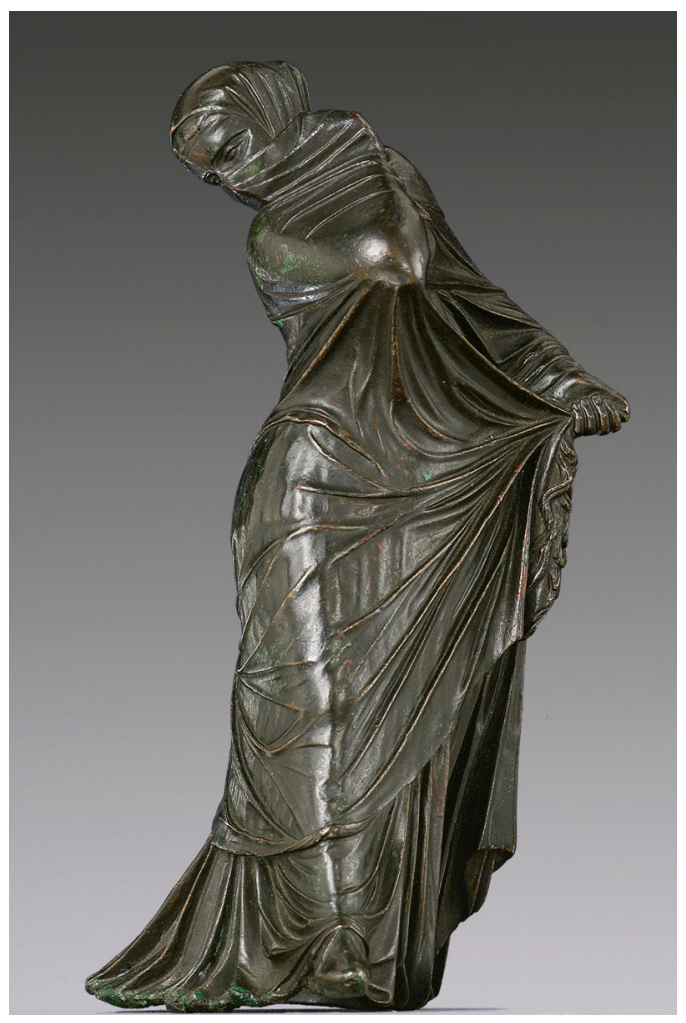

Figure 1. Tanagra statuette of a veiled dancer

Women, on the other hand, should cover their bodies entirely, even veiling their heads and faces when going out in the streets or in presence of men (Llewellyn-Jones, 2003). The figurines found in Tanagra show women in daily clothing, wearing large mantles, which covered their heads, and pieces of cloth falling from their forehead over their faces, leaving just two holes for their eyes (See figure 1).

To what extent the practice of women being heavily-veiled was customary is unknown; but, when compared to men, this clearly shows a huge difference between how men and women should behave in public. Furthermore, it is one of the simplest ways to make students understand how society was constructed in those days and a good indicator of what was expected from women, who should remain inside their homes and as invisible to men as possible (Cairns, 2016).

\section{3.-Rome}

There are several possible ways of illustrating this section, as well as the previous one: we can show photographs of ancient statues and pictures, replicate some dresses, either to let students try them or in small scale, to dress mannequins; but we can also create posters which combine several pictures. The last option becomes particularly interesting when talking about Rome: dress is carefully chosen to recognise social status, political positions and different honours and rewards, so it is better to show all attires classified in a way that all differences are clearly and immediately perceived.

It is not always easy to understand how a figure is draped on a statue, especially in a picture, so to create a poster it may be better to draw the images. For those of us who cannot draw, there is a simple and effective solution: printing one or two pictures, preferably from a well-known statue and copying the silhouette with tracing paper, avoiding details, just drawing a simple figure. On the copied image, we can easily add any relevant details and garments; we add only the necessary colour and then scan the picture, placed 
on a white paper. After we have all the pictures, they only have to be copied-pasted on our document. For our poster on Roman priests (figure 4), male figures are based on the statue of Augustus Pontifex, from the National Roman Museum (figure 2) and feminine figures could be based on a statue of a matron with her daughter, from the Musei Capitolini (figure 3).

Romans were particularly concerned about clothing and its meaning: every priest, politician and military officer wanted the others to know who they were. Therefore, many aspects of social and political importance can be explained through clothing: from the garments used by provincial peoples and barbarians, to its evolution up to the fall of the empire. Here, I suggest helping students to understand how social classes, wealth and status were divided in Roman society using the visual appearance of people, just like any Roman citizen would in the Classical period.

Four groups of garments and adornments should be shown here: those used by priests, politicians, military personnel and simple civilians.

1. Among civilians, a pyramid can be drawn, showing, from the base to the top:

a) Slaves wore simple clothing and short tunics over the knee. The wealthiest families dress their servants with richer colours and bracelets to show the family's social position together with their personal status.

b) Children of both sexes wore tunics and the toga praetexta (Sebesta \& Bonfante, 2001), with the purple stripe for protection. Boys also wore the bulla around their neck as an amulet. The toga would be substituted with adult garments when girls became women and when boys were about 16 years old.

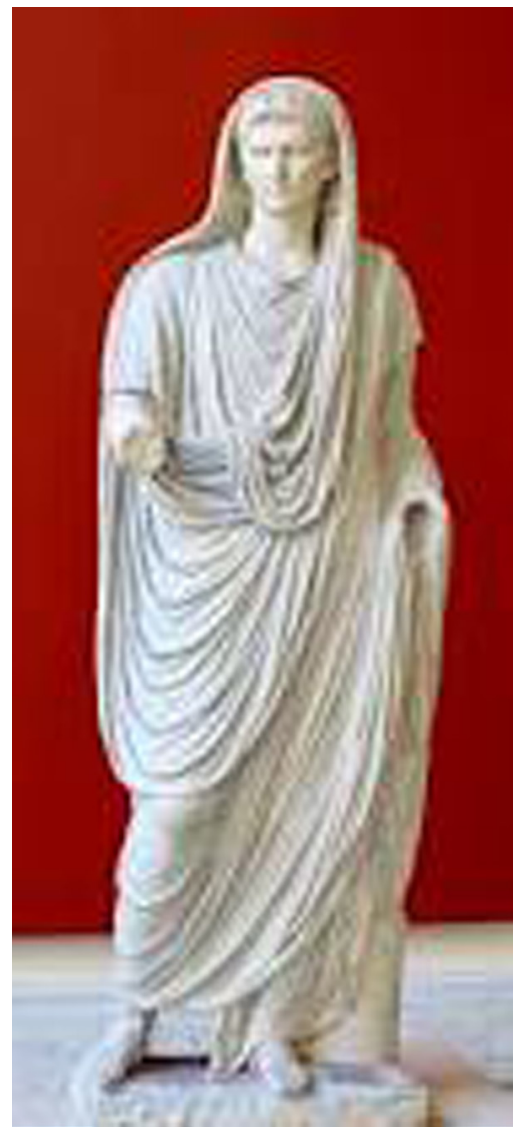

Figure 2. Augustus

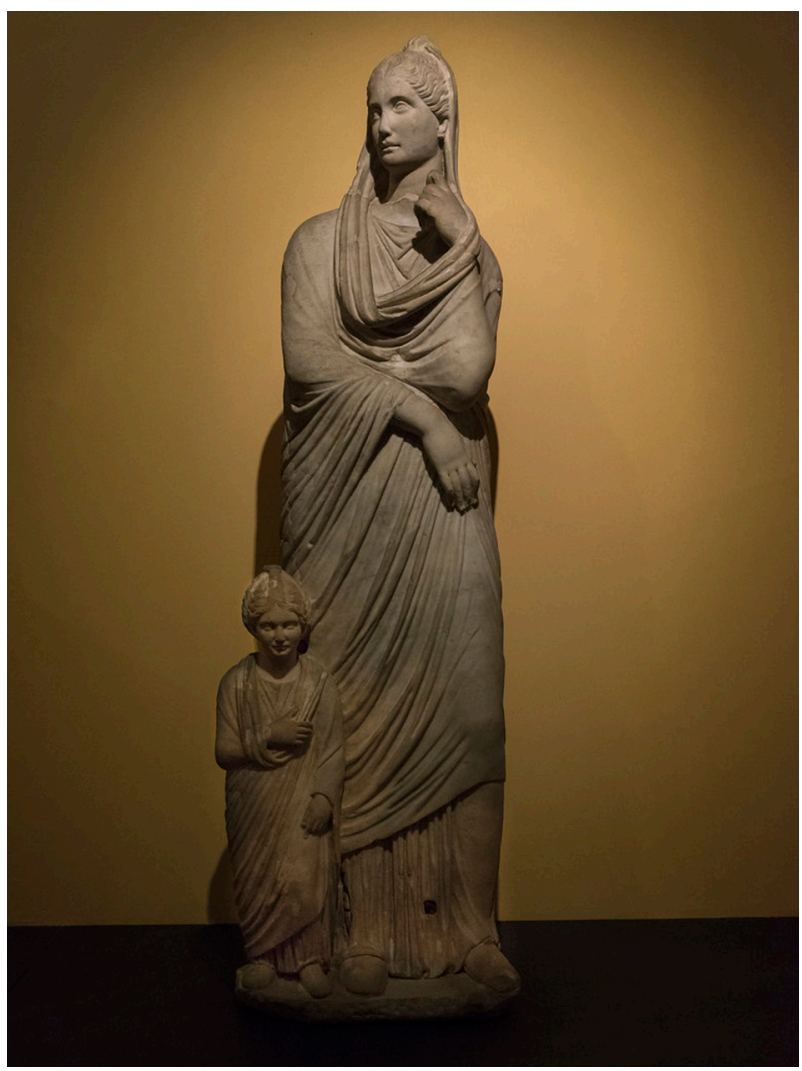

Figure 3. Matron

c) Women wore a long tunic and a stola, a long rectangular piece of cloth (Boatwright, 2011). Typically, the stola covered the head of matrons when they were on the street. Rather than being invisible, Roman women wanted to be seen and to show their status, respectability and wealth with their clothes and jewellery, as we know from the protests against the Poppaean Law. Because of this, they soon began to use the Greek chiton alone or over their tunics, to show colour, jewels, expensive shoes or new hair styles and fabrics like silk.

d) Men's traditional and official garment was the toga. It is supposed that in its origins, it was short, wrapped around the body, since it was possibly worn even at war (Stone, 2001); but then it evolved into a more complicated, long piece of clothing, used only at public ceremonies. When the toga was not required, sometimes a pallium was used over the short-sleeved tunic. Equites and noblemen showed purple stripes on their tunics and patricians had a special type of boot, covering up to the calf, with a painted white moon, known as calcei patricii.

2. Politicians: the most representative garment of the political elites was the toga praetexta, which could only be used by senators, consuls, praetors and curule aediles (Heskel, 2001; Brøns \& Skovmøller, 2017). Senators could also use the mullei, purple-dyed shoes. Away from the classical period, it is always interesting to mention the emperor's clothing, which combined the military palludamentum and crowns, especially during the later empire, with the toga praetexta for civilian life. This became even longer and extremely complicated to drape around the body in the Eastern half of the territory, during the Late Empire. The influence of Eastern fashion, including Greek garments, as well as Parthian or Egyptian, influenced, however, 


\section{Roman priests}

\section{How could they be recognized? Their garments barely change through time.}

They can only wear wool.

The toga, laena and trabea all descend from the Etruscan tebenna.

All wear an adornment that makes them easy to recognize.

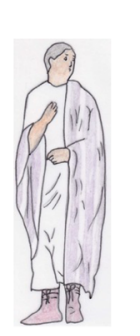

Rex sacrorum:

a remainder of the monarchy

- King's trabea?

- $\quad$ Survived just a symbol: a sacred figure that can not be eliminated.
Pontifex Maximus

- Toga praetexta

- Capite velato

- Created to divide the powers of the expelled king

- With no visible symbols to remember the old monarchy

- Head of the religious system, a role visually perfect for the new emperor

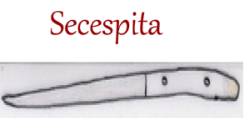

Flamen

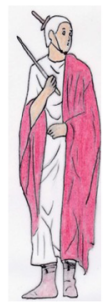

- Galerus/ albogalerus

- Apex

- Offendices

- Trabea/laena

- No knots:

- Did they use a belt?

- How did they tie their calcei patricii?
Arvalis

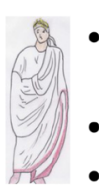

- Toga praetexta

Salius

- Tunica picta

- Spike crown - Ancilia

- White infulae

Fetialis

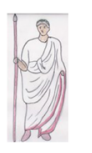

- Toga praetexta Lupercus

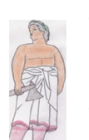

- Sagmina verbena

- Hasta sanguinea

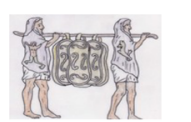

Limus

- Silex/ gladius
Vestalis

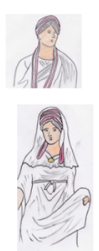

$\bullet$

Infulas

- Suffibulum

- Fibula

Herculaneus nodus

- Palla
Regina

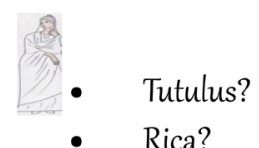

dipped in

milk

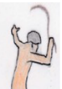

Flaminica
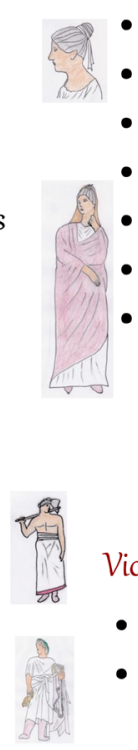

- Tutulus

- Vittae

- Granius

- Rica

- Arculus

- Venenata palla

- Fibula

Figure 4. Poster

some philo-Hellenic emperors, who chose more exotic garments, and so golden cloaks and full purple are described for some emperors and empresses (cf. Tacitus' Annales 12.56 on Agrippina's golden chlamys).

3. Priests: it was important to show their holiness, as a warning for anyone around them to behave accordingly, under the risk of being sacrilegious. We do not have much information on all of the types of priests, but we do know about the Vestals Virgins' seni crines and their use of a veil fastened with a brooch over the chest (Gallia, 2014). Flamines wore a special cap, the galerus; the Diales, wore a cap with a piece of wood on top and fastened with two pieces of untied leather under the chin (Goldberg, 2015). 
They could not wear any knots on their clothes and they wore the calcei patricii. Their wives had their hair on a tutulus, tied with bands of cloth, and they wore a veil fastened with a small branch of pomegranate and a palla. White and purple were the typical colours of all priests, showing their holiness and their connection to the blood which came from sacrifices. They wore only wool, for linen was linked to death, and they used the oblong knife called secespita for their ritual sacrifices. Augurs and haruspices, who participated in military and civilian life, adapted easily to the evolution in fashion and were only recognised by their trabea, a kind of striped toga (Bonfante Warren, 1970), and the lituus, a small staff curved on top that was used by augurs.

4. Military garments: soldiers had various sets of clothing, depending on whether they were expected to march and work or were ready to battle (pro cinctu) (Sumner, 2002; Summer, 2003). They typically wore a short tunic, over the knees, to allow freedom of movement, fastened with a belt around the waist. Leather or metal cuirasses were placed on top of this. On their feet, they would wear their caligae, usually with metal hobnails to avoid tripping, but without them for spies and explorers, so they would not be heard by the enemy. Generals would wear the red palludamentum, and show a crest over their helmets, placed from front to back. Centurions, on the other hand, had their crests running from side to side. During triumphal parades, soldiers would be dressed in a similar equipment, only completely white (Bonfante Warren, 1970).

5. Military equipment is the one which incorporates foreign garments more easily. When fighting in Northern regions, they adopted the braccae from the Gauls. These were some sort of pants worn under the tunic. They also wore woollen socks and hooded cloaks like the caracalla.

6. As a bonus, a small section could be dedicated to military crowns and awards (Stout, 2001), showing the differences between various types of crowns and describing their evolution until they become the insignia of the emperor in Byzantium and European kings during the Middle Ages.

\section{4.-Activities and conclusions}

To make the workshop as interactive as possible, different activities should be included. If the workshop is designed to be conducted in just one session, all the activities could be reserved for the end, after explaining all relevant information. However, since it is probably going to need a longer period of time, some practical exercises can be done at the end of each section, keeping the rest of them as an ending point. This way, students can use the information they have already learnt and the groups can compete against each other.

A timeline and even a map could be drawn, letting students place the main events in the right date and place. For the first section, we could compare different types of fabric and techniques and, if possible, weave a small piece of cloth with hand looms. For the following sections, pictures or reproductions of clothes could be used so that students had to identify them and their use. They could also be asked to identify the origin and status of a person, given a picture or a dressed puppet. In order to connect the experience with modern life, they could also try to identify dress mistakes in movies and nowadays garments that imitate fashion from classical times.

As a final point, a more practical and entertaining activity should be done. The ideal would be to let them dress up or even to make them design and create a garment, but since time, materials and sanitary restrictions may not allow them to do that, it may be cheaper to let them decorate a small jewel. Certain soft materials, such as clay, could be used to carve a figure and so students can decorate a ring or a neck pendant with figures that we can provide them as a model, with either a personal emblem or a divinity that may serve for protection.

An even cheaper and easier option would be to ask participants to draw a person wearing Greek or Roman garments. To make sure they are accurate, we can create a series of cards with the ethnic origins, sex, age and status of people and randomly distribute them so that students have to draw the person they receive. If the group is particularly keen on fashion, they can also try tomodify ancient garments to make them wearable and fashionable today.

Finally, if we choose to create a virtual workshop, something that the last events have forced many of us to do, we could substitute most of the material with infographics and interactive activities. We may consider a virtual visit to certain museums, or at least select a few ancient works so that students can see clothes represented. In this case, the option of ending with a picture may be more manageable, but we can still celebrate a contest among all participants, so that they share a picture of the final product, whether it is a picture, a jewel or a garment.

In summary, this workshop, developing a topic which would at first seem simple, allows teachers to reach a variety of topics relative to society, politics and religion in ancient times in a direct and visual way that cannot be easily achieved by other means. Since it is such a wide topic and so many materials were used, all activities, pictures and samples can be modified depending on our interest and on the availability of material we have. It is even possible to create different workshops, focused on different aspects of fashion and so adapted to several groups of students.

\section{References}

Boatwright M T (2011) Women and gender in the Forum Romanum. Transactions of the American Philological Association, 141, pp. 105-141.

Bonfante Warren L (1970) Roman triumphs and Etruscan kings: the changing face of the triumph. In The Journal of Roman Studies 60, pp. 49-66.

Brøns C and Skovmøller A (2017) Colour-coding the Roman toga: the materiality of textiles represented in ancient sculpture. Antike Kunst 60, pp. 55-79.

Cairns D S (2016) Clothed in shamelessness, shrouded in grief. The role of 'garment' metaphors in ancient Greek concepts of emotion. In Fanfani, G., Harlow, M., Nosch, M.-L. (eds.) Spinning Fates and the Song of the Loom: The Use of Textiles, Clothing and Cloth Production as Metaphor, Symbol, and Narrative Oxford: Oxbow, pp. 25-41.

Gallia A (2014) The Vestal habit. In Classical Philology, vol. 109, n³, pp. 222-240.

Goldberg C (2015) Priests and politicians: rex sacrorum and flamen Dialis in the middle Republic. In Phoenix, vol. 69, n 3/4, pp. 334-354.

Heskel J (2001) Cicero as evidence for attitudes to dress in the Late Republic. In Sebesta J and Bonfante L (eds.) The World of Roman Costume, Winsconsin: The University of Winsconsin Press, pp. 133-145.

Llewellyn-Jones L (2003) Aphrodite's Tortoise: the veiled woman of ancient Greece, Classical Press of Wales.

Pavlou M (2009) Reading Medea through her veil in the Argonautica of Apollonius Rhodius. Greece \& Rome, 56:2, pp. 183-202.

Sebesta J and Bonfante L (eds.) (2001) The World of Roman Costume. Wisconsin: The University of Wisconsin Press.

Stone S (2001) The toga: from national to ceremonial costume. In Sebesta J and Bonfante L (eds.) The World of Roman Costume, Winsconsin: The University of Winsconsin Press, pp. 77-100.

Stout A M (2001) Jewelry as a symbol of status in the Roman Empire. In Sebesta J and Bonfante L (eds.) The World of Roman Costume, Winsconsin: The University of Winsconsin Press, pp. 77-100

Sumner G (2003) Roman Military Clothing (2) AD 200-400. Oxford: Osprey Publishing

Sumner G (2002) Roman Military Clothing (1) 100 BC-AD 200. Oxford: Osprey Publishing 